\title{
PENINGKATAN KECAKAPAN HIDUP ANAK PANTI ASUHAN YATIM DI KARANGANYAR MELALUI PELATIHAN WIRAUSAHA CISTIK SAYURAN
}

\author{
Endang Susilowati ${ }^{1{ }^{*}}$, Sri Retno Dwi Ariani ${ }^{1)}$, Elfi Susanti $\mathrm{VH}^{1)}$ \\ 1) Prodi Pendidikan Kimia FKIP, Universtas Sebelas Maret \\ Email: endwati@yahoo.co.id
}

\begin{abstract}
The orphanage is a place to accommodate, nurture and care for orphans and the poor. The existence of this orphanage becomes an important part for the continuity of education foster children. In addition to formal education, non-formal education is required in the form of certain skills to be provision of life skills. Based on the results of the survey of foster children living in Panti Asuhan Yatim Putri Aisyiyah and Panti Asuhan Yatim Putra Muhammadiyah in Karanganyar have sufficient time to spare and they do not have the provision of skills that are meaningful for his life. Therefore they need to be given life skills provision in the preparation of entrepreneurial skills.

For the realization of orphanage children with provision of suffice life skills, the team of community service from FKIP UNS provides training of entrepreneurs vegetables cheese stick. The training is done through lacturing and practicing. The subject of lecturing is the theory of vegetable cheese stick entrepreneurship. Further practicing on how to produce vegetables chesee stick with a variety of vegetables are used. After the competent participants make the products that have been taught, then the team of servants accompany in the packaging and marketing.

Based on the implementation of the training vegetable cheese stick entrepreneurship and evaluation directly and through questionnaire, the activity was greeted positively by all participants. Participants actively participate in all activities and are eager to follow up with production and marketing. This entrepreneurship training has increased life skills for foster children in Panti Asuhan Yatim Putri Aisyiyah and Panti Asuhan Yatim Putra Muhammadiyah.
\end{abstract}

Keywords: Life Skills, Orphanage, Entrepreneurship, Vegetables Cheese stick 


\section{PENDAHULUAN}

Panti asuhan merupakan lembaga yang bergerak di bidang sosial dengan cara menampung, menghidupi dan menyekolahkan anak yatim, yatim piatu dan anak terlantar (dhuafa). Menurut hasil penelitian Save the Children, 94\% dari anak asuhan yatim piatu di Indonesia "menjadi" yatim piatu karena alasan kemiskinan. Orang tua mereka tidak mampu untuk menafkahi mereka dengan layak, sehingga mereka "menitipkan" anakanak mereka di rumah-rumah pengasuhan yatim piatu. (Iqbal, 2010; Yuniana, 2012)

Di kabupaten Karanganyar terdapat beberapa panti asuhan yang menarik mendapatkan perhatian diantaranya adalah Panti Asuhan Yatim Putra Muhammadiyah Pimpinan Daerah Muhammadiyah (PDM) Karanganyar dan Panti Asuhan Putri Aisyiyah yang berada di bawah naungan Pimpinan Daerah Aisyiyah (PDA) Karanganyar. Panti Asuhan Putra Muhammadiyah didirikan pada tahun 1990 yang saat ini menampung sebanyak 43 anak. Mereka tersebar di berbagai jenjang pendidikan muai dari SMP 8\%, SMA/SMK 80\% dan perguruan tinggi 12\%. Panti Asuhan Putri Aisyiyah didirikan pada tahun 1994 saat ini menampung sebanyak 41 anak. Mereka tersebar di berbagai jenjang pendidikan mulai dari Sekolah Dasar sampai Perguruan Tinggi.

Berdasarkan survei di Panti Asuhan Yatim Putra Muhammadiyah dan Panti Asuhan Putri Aisyiyah, terdapat temuan bahwa anak asuh masih banyak waktu luang dan belum ada kegiatan untuk meningkatkan kecakapan hidup, padahal mereka memiliki potensi yang besar mengingat $85 \%$ sedang menempuh pendidikan di SMA/SMK dan PT. Melihat kenyataan ini maka yang dibutuhkan oleh panti Panti Asuhan Yatim Putra Muhammadiyah dan Panti Asuhan Yatim Putri Aisyiyah adalah memberikan bekal kewirausahaan yang menguntungkan dari sisi ekonomi sehingga anak asuh mendapatkan bekal kecakapan hidup (life skill). Dengan kecakapan hidup, maka anak asuh akan 
memiliki pengetahuan, keterampilan dan sikap yang dibutuhkan dalam memasuki dunia kerja baik bekerja secara mandiri (wirausaha) dan/atau bekerja pada suatu perusahaan produksi/jasa dengan penghasilan yang semakin layak untuk memenuhi kebutuhan hidupnya (Depdiknas, 2004). Salah satu jenis kecakapan hidup adalah kecakapan hidup bekerja (Occupational Skill) yang meliputi kecakapan memilih pekerjaan, persiapan keterampilan kerja, latihan keterampilan, kesadaran untuk menguasai berbagai keterampilan, merancang dan melaksanakan proses pekerjaan dan menghasilkan produk barang dan jasa (Solikhin, 2011)

Di sisi lain, saat ini terdapat masalah pada jajanan anak-anak terutama di sekolah. Beredarnya jajanan di sekolah khususnya tingkat SD dan SMP saat ini cukup mempriharinkan karena di samping jajanan yang tidak sehat juga membahayakan bagi kesehatan anak. Kebanyakan jajanan di sekolah menggunakan bahan kimia berbahaya untuk mendapatkan cita rasa yang enak dan penampilan yang menarik. Oleh karena itu perlu jajanan alternatif yang menarik dan sehat. Berdasarkan pantauan BPOM, jajan sekolah tidak sehat paling banyak dijual oleh pedagang keliling yang berjualan di luar area atau pagar sekolah. Sedangkan di kantin, BPOM berupaya bekerja sama dengan pihak sekolah untuk dapat memberikan pengarahan pada penjaga atau pemilik kantin. Badan Pengawas Obat dan Makanan (BPOM) masih menemukan adanya jajanan anak di sekolah yang mengandung bahanbahan tidak aman untuk kesehatan. Tercatat bahwa hampir 40 persen pangan jajanan anak sekolah di seluruh Indonesia mengandung bahan berbahaya seperti boraks, formalin, dan zat pewarna. (“Kompas”, 23 Mei, 2012 ) Pemanfaatan potensi anak panti perlu dilakukan untuk memecahklan masalah panti yaitu kecakapan hidup anak panti masih kurang dan masih adanya waktu luang yang belum dimanfaatkan secara maksimal. Anak panti yang sebagian 
besar menginjak dewasa perlu secara sinergis juga sebagai alternatif diberdayakan dengan cara pemberian pemecahan masalah bagi beredarnya keterampilan yang terbimbing makanan yang berbahaya bagi anakmengingat keterampilan yang mereka anak.

miliki masih terbatas. Salah satu bentuk

Bentuk wirausaha makanan keterampilan yang dapat diberikan sehat yang potensial untuk diberikan adalah wirausaha makanan (cemilan) sehat.

Pemberian bekal wirausaha ini diharapkan dapat dijadikan sebagai alternatif untuk pola pembinaan anak asuh di pantin asuhan yang akan memberikan peningkatan kecakapan hidup. Bekal kecakapan hidup ini akan dapat menciptakan wirausaha mandiri ketika mereka sudah keluar dari panti. Dengan kecakapan hidup yang baik, maka akan berdampak juga pada meningkatnya profesionalitas kerja bagi calon tenaga kerja muda yang termotivasi, berkualitas, terampil, kreatif dan bertanggung jawab (purnomo dan Rochana, 2013). Dengan Wirausaha mandiri maka mereka juga berperan dalam menjadi penggerak, pengendali, dan pemacu perekonomian suatu bangsa (Suryana, 2003). Di samping itu wirausaha jajanan sehat ini adalah membuat dan memasarkan jajanan sehat yang dibutuhkan masyarakan sehari-hari khususnya anak-anak, diantaranya adalah cemilan sehat cistik sayuran. Cheese Stick (atau cistik) adalah camilan yang disenangi karena rasanya yang gurih dan "kriuk"nya. Tidak berbeda dengan penganan ringan lainnya, cheese stick dianggap sebagai makanan selingan atau camilan teman minum teh atau sebagai teman bagi makanan lainnya, misalnya mie bakso. Namun, bagaimana kalau penganan gurih ini dipadukan dengan sayuran, hasilnya tentu adalah sebuah perpaduan yang lezat dan tentu saja sehat. Cistik sayuran atau Vegetable Cheese Stick menjadi makanan camilan yang menyehatkan. Sayuran yang mengandung banyak serat dapat melengkapi gurihnya cistik sehingga menjadi sebuah makanan 
selingan yang bukan sekedar selingan, tapi juga menyehatkan karena sayuran yang terkandung di dalamnya. Sayuran yang biasanya tidak menarik untuk dimakan dalam bentuk biasa, kini dapat dinikmati dengan rasa yang lebih menyenangkan. Anak-anak pun yang biasanya kurang menyukai sayursayuran, dapat menikmatinya karena mereka sangat menyukai makanan ringan layaknya kerupuk (Nenden, 2016). Cistik sayuran merupakan jenis cemilan berbagan baku gandum dengan tambahan keju dan sayuran. Dari sisi kandungan gizi maka cemilan ini merupakan jenis makanan yang banyak mengandung gizi lengkap. Oleh karena itu kandungan sayuran pada cistik menjadi hal yang menarik karena akan cemilan ini bisa sebagai alternatif untuk mencukupi kebutuhan gizi dan serat bagi anak-anak.

Strategi yang dilakukan untuk memberi ketrampilan wirausaha cemilan sehat cistik adalah melalui penyuluhan secara teori, pelatihan dengan praktek langsung dan pendampingan. Materi penyuluhan adalah teori tentang wirausaha dan peluang usaha kecil menengah, pengemasan dan pemasaran produk. Selanjutnya dilakukan pelatihan cara cistik sayuran dengan menggunakan 3 jenis sayuran yaitu wortel, bayam, kenikir. Setelah peserta mahir membuat produk-produk yang telah diajarkan, maka tim pengabdi mendampingi dalam pengemasan dan pemasarannya.

\section{METODE / APLIKASI}

Metode pelaksanaan kegiatan yang akan dilakukan untuk mengatasi permasalahan adalah sebagai berikut:

\section{Penyuluhan secara teori}

Tujuan penyuluhan ini adalah memberikan ilmu dan wawasan baru kepada anak asuh panti asuhan yatim tentang wirausaha dan peluang usaha rumahan, sehingga terbuka pikiran serta tumbuh minat dan motivasi dalam diri mereka untuk berwirausaha. Materi penyuluhan adalah wirausaha dan peluang usaha rumahan, prinsip dasar produksi cemilan sehat cistik sayuran, pengemasan dan pemasaran produk. Penyuluhan ini disampaikan dalam 
bentuk ceramah menggunakan media LCD dan dilanjutkan dengan tanya jawab kepada peserta. Dengan penyuluhan para peserta diharapkan benar-benar memahami wirusaha yang akan dilakukan.

\section{Pelatihan dengan praktek langsung}

Materi pelatihan adalah cara pembuatan cemilan sehat cistik sayuran. Kegiatan ini bertujuan untuk memberikan keterampilan tentang cara produksi, pengemasan dan pemasaran produk. Pelatihan tersebut disampaikan dalam bentuk ceramah yang dilanjutkan dengan eksperimen langsung dan tanya jawab tentang cara pembuatananeka produk cemilan sehat cistik sayuran. Pelatihan dilaksanakan sampai semua peserta mahir mempraktekkan sendiri.

Setelah peserta mahir membuat produk, maka diberikan pembekalan cara pengemasan produk dengan kemasan sederhana dan memberi label. Hasil produk yang telah dikemas kemudian dipasarkan di lingkungan Muhammadiyah Karanganyar

\section{B. Prosedur kegiatan}

Kegiatan pengabdian dilakukan melalui prosedur sebagai berikut:

1. Sosialisasi kegiatan yang meliputi koordinasi dengan mitra, terkait dengan penyusunan jadwal kegiatan dan persiapan penyuluhan dan pelatihan

2. Penyuluhan tentang wirausaha dan peluang usaha rumahan

3. Penyuluhan tentang prinsip dasar pembuatan cistik sayuran.

4. Penyuluhan tentang pengemasan dan pemasaran produk cistik sayuran.

5. Penyuluhan manajemen produksi dan pemasaran sehingga wirausaha bisa berlanjut secara terus menerus

6. Pelatihan (praktek langsung) untuk pembuatan cistik sayuran.

7. Pelatihan (praktek langsung) tentang pengemasan cistik sayuran.

8. Evaluasi kegiatan dengan teknik angket dan wawancara untuk mengetahui tingkat keberhasilan pelatihan wirausaha cemilan sehat 
cistik sayuran.

\section{Partisipasi Mitra}

Partisipasi mitra dalam pelaksanaan kegiatan ini adalah partisipasi aktif, dari mulai perencanaan kegiatan, penyusunan jadwal penyuluhan dan pelatihan. Partisipasi mitra akan dievaluasi. Evaluasi akan dilaksanakan selama dan setelah pelaksanaan kegiatan penyuluhan dan pelatihan. Selama pelaksanaan kegiatan dilakukan evaluasi dengan metode pengamatan langsung oleh Tim Pengabdian. Sedangkan setelah pelaksanaan kegiatan dilakukan evaluasi dengan metode pengamatan terhadap hasil kegiatan dan metode angket. Kriteria evaluasi meliputi kasadaran dan antusiasme peserta penyuluhan dan pelatihan dalam mengikuti kegiatan serta tingkat kemahiran peserta dalam mempraktekkan sendiri pada pembuatan cistik sayuran, pengemasan dan pemasarannya.

\section{HASIL, PEMBAHASAN DAN DAMPAK}

Kegiatan pengabdian kepada masyarakat yang telah dilakukan melalui beberapa tahapan kegiatan yaitu: kegiatan pendahuluan (sosialisasi), kegiatan penyuluhan, kegiatan pelatihan dan kegiatan tindak lanjut. Berikut ini akan dijelaskan hasil pengamatan pada setiap kegiatan.

Kegiatan pertama merupakan pertemuan pendahuluan atau sosialisasi yang yang terdiri dari:

1. Sosialisasi dengan pengurus panti asuhan yatim

Pada pertemuan dengan pengurus panti ini dibahas tentang rencana kegiatan pengabdian yang akan dilaksanakan oleh Tim pengabdian dari UNS. Menurut hasil sosialisasi ini diperoleh informasi bahwa peserta yang akan ikut dalam pelatihan adalah sekitar 20 anak dari panti putri dan 20 anak dari panti putra dengan berbagai latar belakang pendidikan dari SMP sampai perguruan tinggi.

2. Sosialisasi dengan peserta pelatihan (anak asuh panti) 
Pada pertemuan ini Tim Pengabdian dari UNS memberikan sosialisasi kegiatan pengabdian yang akan dilaksanakan baik di panti asuhan putra maupun panti asuhan putri. Pada sosialisasi ini juga dilakukan pembagian kelompok untuk kegiatan pelatihan yang akan dilakukan berikutnya. Tiap kelompok terdiri dari 4-5 anak.

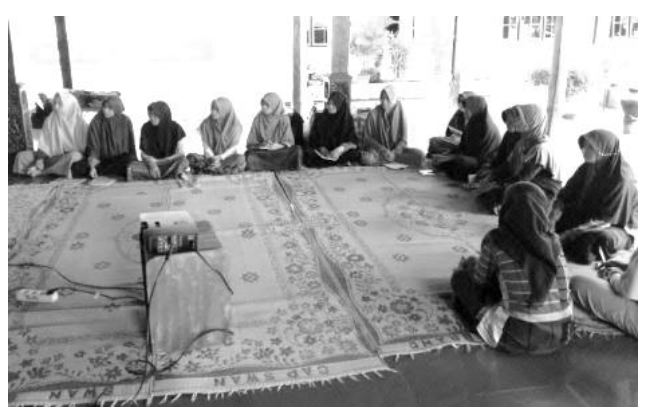

Gambar

1. Peserta sedang mendengarkan sosialisasi dari tim pengabdian (a) Panti putri, (b) Panti putra

Kegiatan kedua adalah penyuluhan (ceramah) disertai diskusi tentang pembuatan 3 macam cistik sayuran yaitu cistik wortel, cistik bayam, cistik kenikir. Materi ceramah meliputi bahan yang digunakan dan fungsinya beserta cara pembuatan masing-masing produk.
Pada ceramah ini diberikan contohcontoh produk-produk cistik yang sudah beredar di pasaran. Disamping itu peserta diberikan materi melalui pemutaran video pembuatan cistik dari menyiapkan alat sampai pengemasan. Hal ini dilakukan untuk memotivasi peserta untuk berwirausaha mandiri berbasis kimia terapan. Dalam kegiatan ceramah ini peserta diberi kesempaan untuk bertanya/berdiskusi dengan pembicara. Kegiatan saat penyuluhan dapat dilihat pada Gambar 2.

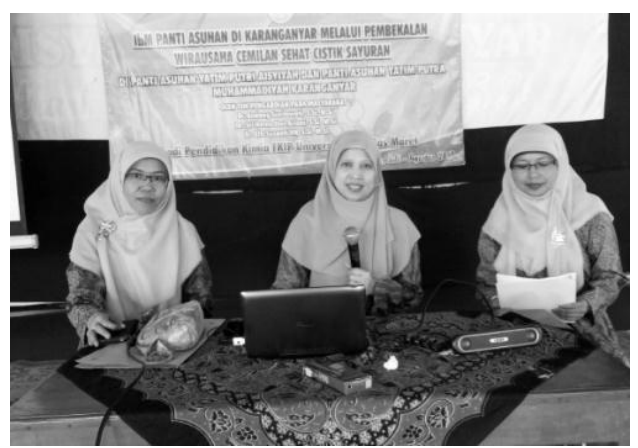

Gambar 2. Tim pengabdian sedang melakukan penyuluhan melalui ceramah dan diskusi

Pertemuan ketiga adalah mengadakan pelatihan pembuatan 3 cistik sayuran dan original. Pelatihan dilakukan dengan cara praktek langsung 
secara kelompok dengan dibagi menjadi

5 kelompok. Pada pelatihan ini beberapa peserta masih cukup faham tentang bahan-bahan yang digunakan karena bahan yang digunakan memang sering mereka jumpai di dapur.

Adapun bahan-bahan utama yang digunakan adalah tepung terigu, tepung tepung maizena, keju, margarin dan sayuran. Cara pembuatan cistik sayuran cukup mudah. Pertama-tama dicampurkan tepung terigu dan tepung maizena. Kemudian telur kocok lepas ditambahkan pada campiuran tepung dan diaduk rata. Selanjutnya ditambahkan mentega, keju dan sayuran yang telah dihaluskan. Adonan diaduk sampai homogen dan kalis. Kemudian adonen dicetak dengan mesin penggiling mei dengan ukuran tertentu. Hasil cetakan kemudian digoreng dengan minyak yang banyak sampai menguning. Cistik yang telah matang kemudian didinginkan dan dikemas.

Pengemasan cistik bisa dilakukan dengan menggunakan berbagai kemasan, misalnya toples, tabung mika atau plastik standing pouch. Supaya kemasan lebih menarik, maka diberi label kemasan dengan mencantumkan merek dan keterangan lain. Hasil pengemasan cistik yang telah dibuat dapat dilihat pada Gambar 3.

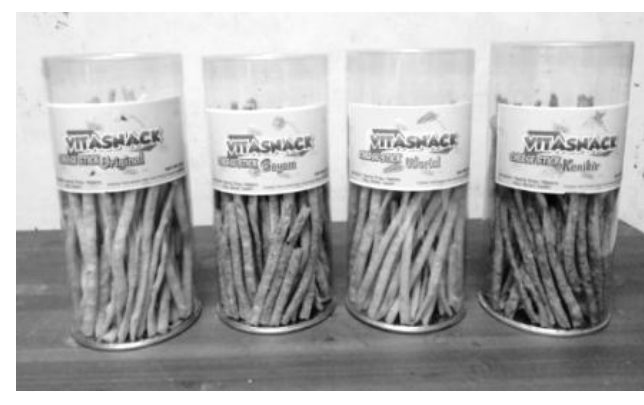

Gambar 3. Cistik dengan kemasan (a) Tabung mika, (b) Plastik standing pouch

Pada pelatihan ini semua peserta berhasil membuat produk berupa cistik sayuran dengan kualitas yang tidak kalah dengan yang ada di pasaran. Untuk menguji performace dan tingkat kesukaan produk, maka dilakukan uji organoleptik terhadap cistik yang hasilkan. Jumlah panelis ada 12 orang dewasa dengan 8 wanita dan 4 pria. Score 1=kurang, 2=cukup dan 3= baik. Dari Gambar 4 menunjukkan bahwa cistik yang dihasilkan cukup baik dari aspek rasa, tampilan, tekstur dan 
aroma. Dan rata-rata panelis berhasil. Adapun indikator keberhasilan menyatakan suka dengan produk yang dari kegiatan pengabdian kepada cistik yang dihasilkan. Oleh karena itu masyarakat khususnya bagi Anak asuh cistik ini cukup layak untuk dijual di panti asuhan yatim putra pasaran. Sebagai tindak lanjut dari Muhammadiyah dan panti asuhan pelatihan pembuatan cistik sayuran dan yatim putri aisyiyah sebagai peserta pengemasannya adalah display produk di toko kelontong seperti pada Gambar 5.

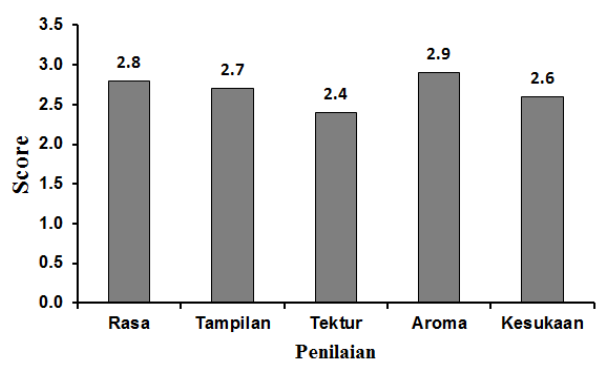

Gambar 4. Uji organoleptik dari cistik hasil pelatihan

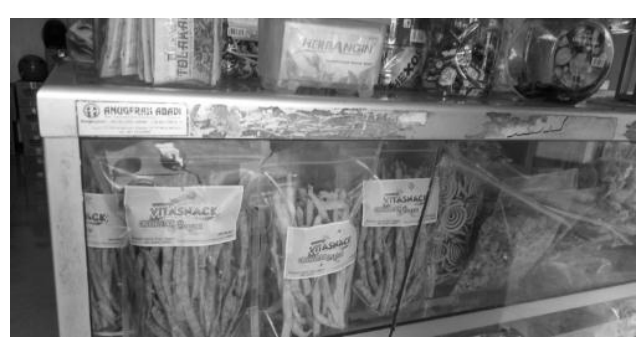

Gambar 5. Display produk di Toko kelontong pelatihan adalah terlihat: (1) Para peserta aktif menyampaikan tanggapan dan pertanyaan tentang cara pembuatan cistik sayuran. (2) Para peserta termotivasi untuk berusaha meningkatkan ketrampilan dirinya pada saat pelatihan pembuatan cistik sayuran. (3) Para peserta termotivasi untuk berwirausaha mandiri produk cistik sayuran.

Umpan balik kegiatan dari peserta dilakukan dengan mengisian angket oleh para peserta. Hasil pengolahan data angket balikan dapat dilihat pada Gambar 5. Adapun indikator umpan balik dapat dilihat pada Tabel 1. Adapun Peniaian terhadap masing-masing indikator Dari evaluasi dengan adalah: 1=sangat tidak setuju, 2=tidak pengamatan dan wawancara di setuju, 3=ragu-ragu, 4=setuju dan lapangan secara langsung, maka 5=sangat setuju. kegiatan pengabdian ini bisa dikatakan 
Tabel 1. Indikotor evaluasi pada

kegiatan pengabdian

\begin{tabular}{|c|c|}
\hline No & Indikator \\
\hline 1 & $\begin{array}{l}\text { Peserta merasa tertarik } \\
\text { dengan materi wirausaha } \\
\text { cistik sayuran }\end{array}$ \\
\hline 2 & $\begin{array}{l}\text { Secara teori materi } \\
\text { pelatihan wirausaha cistik } \\
\text { sayuran mudah difahami }\end{array}$ \\
\hline 3 & $\begin{array}{l}\text { Materi pelatihan } \\
\text { pembuatan cistik sayuran } \\
\text { mudah dipraktekan sendiri }\end{array}$ \\
\hline 4 & $\begin{array}{l}\text { Penyaji materi cukup } \\
\text { memuaskan dalam } \\
\text { menyampaikan materi }\end{array}$ \\
\hline 5 & $\begin{array}{l}\text { Penyaji berinteraksi dengan } \\
\text { baik dengan peserta dalam } \\
\text { kegiatan }\end{array}$ \\
\hline 6 & $\begin{array}{l}\text { Sarana dan prasarana } \\
\text { pelatihan memenuhi } \\
\text { kebutuhan peserta }\end{array}$ \\
\hline 7 & $\begin{array}{l}\text { Waktu yang disediakan } \\
\text { cukup untuk menguasai } \\
\text { materi yang disampaikan }\end{array}$ \\
\hline 8 & $\begin{array}{l}\text { Peserta merasa tertarik } \\
\text { untuk mengikuti kegiatan } \\
\text { serupa di lain waktu }\end{array}$ \\
\hline 9 & $\begin{array}{l}\text { Kegiatan pelatihan } \\
\text { menambah wawasan dalam } \\
\text { berwirausaha }\end{array}$ \\
\hline 10 & $\begin{array}{l}\text { Pelatihan ini memotivasi } \\
\text { peserta untuk berwirausaha } \\
\text { mandiri }\end{array}$ \\
\hline 11 & $\begin{array}{l}\text { Peserta merasa tertarik } \\
\text { untuk menindaklanjuti } \\
\text { kegiatan ini dengan } \\
\text { berwirausaha cistik }\end{array}$ \\
\hline 12 & $\begin{array}{l}\text { Secara keseluruhan kegiatan } \\
\text { pelatihan memuaskan } \\
\text { peserta }\end{array}$ \\
\hline
\end{tabular}

13 Produk berupa cistik yang dihasilkan telah layak untuk dipasarkan

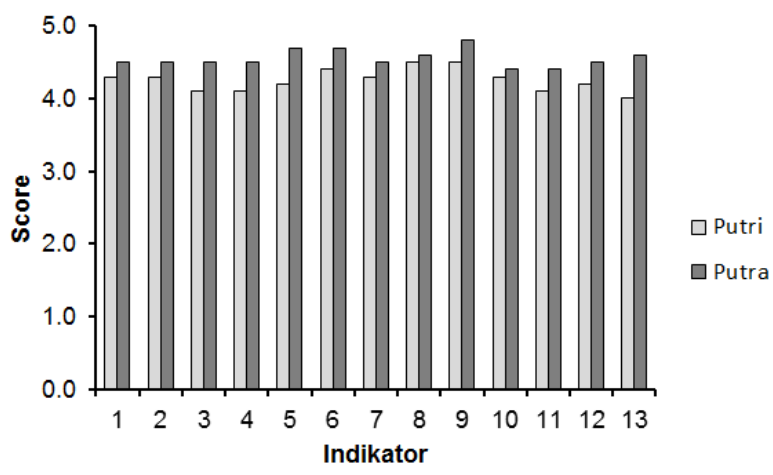

Gambar 5. Score penilaian terhadap masing-masing indikator pada angket balikan

Dari Tabel 1 dan Gambar 5 terlihat bahwa indikator memiliki score di atas 4. Hal ini mengindikasikan peserta sangat tertarik dengan materi wirasusaha cistik sayuran karena baik secara teori maupun praktek, wirausaha ini mudah difahami. Hal ini kemungkinan disebabkan bahan-bahan yang digunakan cukup mudah dikenali dan beberapa sudah sering digunakan memasak. Disamping itu penyajian yang cukup menarik dan interaktif dari tim pengabdian juga menambah ketertarikan dari peserta. Sarana dan prasarana yang mendukung serta waktu 
yang cukup memadahi, membuat proses pelatihan berjalan dengan lancar. Kegiatan ini sangat menambah wawasan bagi peserta dan dapat memotivasi para peserta untuk wirausaha mandiri. Para peserta juga merasa tertarik untuk menindaklanjuti kegiatan ini dengan berwirausaha cistik. Cistik sayuran yang dihasilkan selama pelatihan cukup layak untuk dipasarkan. Secara keseluruhan kegiatan pelatihan memuaskan peserta. Oleh karena itu kegiatan serupa masih perlu diberikan kepada anak asuh panti asuhan sehingga kecakapan hidup semakin semakin meningkat.

Adapun dampak dari kegiatan yang telah dilaksanakan adalah: (1) Para peserta mengetahui teori tentang pembuatan cistik sayuran. (2) Para peserta memiliki ketrampilan membuat cistik sayuran dan pengemasannya. (3) Para peserta meningkat kecakapan hidupnya dan tumbuh jiwa kewirausahan khususnya wirausaha cistik sayuran.

\section{PENUTUP}

Berdasarkan hasil pelaksanaan kegiatan pembekalan ketrampilan wirausaha cistik sayuran dapat disimpulkan sebagai berikut:

1. Kegiatan pengabdian terlaksana sesuai dengan rencana

2. Kegiatan pengabdian dari sosialisasi, penyuluhan dan pelatihan mendapatkan sambutan yang baik dari peserta baik dari Panti Asuhan Yatim Putri Aisyiyah maupaun Panti Asuhan yatim Putra Muhammadiyah

3. Para peserta kegiatan memiliki pengetahuan tentang wirausaha cistik sayuran dan memiliki ketrampilan membuat dan mengemas produk cistis sayuran

4. Para peserta meningkat kecakapan hidupnya dan tumbuh jiwa kewirausahan khususnya wirausaha cistik sayuran 


\section{UCAPAN TERIMA KASIH}

Terima kasih kami ucapkan kepada

Direktorat Riset dan Pengabdian

Masyarakat, Kementrian Riset

Teknologi dan Pendidikan Tinggi,

Rektor, Ketua LPPM, Dekan FKIP dan

Ketua Prodi Pendidikan Kimia

Universitas Sebelas Maret, serta Mitra

IbM Panti Asuhan Yatim Putri Aisyiyah

dan Panti Asuhan Yatim Putra

Muhammadiyah.

\section{REFERENSI}

Depdiknas, 2004, Pengembangan

Model Pendidikan Kecakapan Hidup

(Life Skill), Jakarta: Pusat Kurikulum

Balitbang Depdiknas

labal, S., 2010, Anak Yatim dan Fakir

Miskin... dan Iman Kita, https://tajarrud. wordpress.com, diakses $15 \mathrm{Mei}$ 2016

Kompas, 23 Mei, 2012, 40 Persen Jajanan Sekolah Mengandung Bahan Berbahaya, www.kompas.com, diakses 25 Mei 2016

Nenden, N, 2016, Sayuran sehat dalam Cistik, http://www.cistik.com/, diakses 25 Mei 2016
Purnomo, Dian., Rochana, Erna. 2011. Pola Pembinaan Anak di Panti Asuhan. Jurnal Sociologie. Vol.1, No. $4: 344-353$

Solikhin, Ahmad. 2011, Konsep Program Pendidikan Kecakapan Hidup, http://visiuniversal.blogspot.co. id. Diakses 10 Februari 2017

Suryana, 2003, Kewirausahaan, Pedoman Praktis Kiat dan Proses Menuju Sukses, Bandung: Salemba Empat

Yuniana, 2012, Kesejahteraan Subjektif Pada Yatim Piatu (Mustadh'afin), Skripsi (tidak diterbitkan). Fakultas Psikologi Universitas Ahmad Dahlan Yogyakarta 


\section{BIODATA PENELITI}

Dr. Endang Susilowati, S.Si., M.Si.

Tenaga pendidik atau dosen pada program studi Pendidikan Kimia Fakultas Keguruan dan IImu Pendidikan Universitas Sebelas Maret. Lahir di Sragen pada 17 Januari 1970. Pengalaman penelitian dan pengabdian pada masyarakat diantaranya Peningkatan Kecakapan Hidup Anak Panti Asuhan Yatim Di Karanganyar Melalui Pelatihan Wirausaha Cistik Sayuran. 